\title{
RELIABILTY OF A ROAD TEST AFTER STROKE
}

\author{
Abiodun Emmanuel Akinwuntan, Willy De Weerdt, Hilde Feys \\ Department of Rehabilitation Sciences \\ Faculty of Physical Education and Physiotherapy \\ Katholieke Universiteit Leuven \\ Belgium \\ Guido Baten, Patricia Arno \\ CARA \\ Belgian Road Safety Institute \\ Brussels, Belgium \\ Carlotte Kiekens \\ Department of Physical Medicine and Rehabilitation \\ University Hospital Pellenberg \\ Katholieke Universiteit Leuven \\ Belgium
}

\begin{abstract}
Background: Despite physical, perceptual and cognitive impairments, amongst others, which might affect driving after stroke, some patients have demonstrated the ability to resume safe driving. Such patients are identified following strictly administered predriving evaluations. The road test is generally acclaimed to be the most valid test of driving performance. Aim: The purpose of this study was to determine the reliability of the road test when performed by stroke patients in Belgium. Method: This was a prospective study of a predriving evaluation at the Belgian Road Safety Institute. Thirty subjects with sequelae of stroke were included. Subjects were accompanied and evaluated during the road test by one of two assessors (A or B) from the road safety institute in an automatic car fitted with a video camera for recording driving performance. Inter-rater reliability was evaluated by comparing results from (1) real-life performance and video recording and (2) between-video judgements. Results: Most sub-items of the road test showed $>80 \%$ scoring agreement between the various evaluations. Intraclass correlation coefficient (ICC) of the items varied from -0.08 to 1.0. ICC of the overall performance was 0.62 when real-life scores were compared with video evaluations and 0.80 in video versus video comparison. Conclusion: Driving is important for optimal participation in daily and social activities. The reliability of assessing overall performance of the on-road test is moderately high and better when assessed using same evidence. Yet, the reliability of some items needs further attention.
\end{abstract}

\section{ACKNOWLEDGEMENTS}

The primary author expresses profound appreciation to the Belgian Road Safety Institute, Brussels, Belgium, particularly the CARA section, for their support, cooperation and funding to participate in the conference. I also acknowledge the financial support of RIVA(vzw), Brussels, Belgium towards enabling my participation at the conference. The author acknowledges the 
Interfaculty Council for Development Co-operation Scholarships Programme of the Katholieke Unversiteit Leuven, Belgium for funding support of his doctoral education.

\section{REFERENCES}

Akinwuntan AE, Feys H, De Weerdt W, Pauwels J, Baten G, Strypstein E. 2002. Determinants of driving after stroke. A retrospective study. Arch Phys Med Rehabil; 83:334-341.

De Raedt R. 2000. Cognitive/Neuropsychological functioning and compensation related to car driving performance in older adults. Vrije Unversiteit Brussel (Belgium): Doctoral thesis. p. 182-194.

Duncan PW, Goldstein LB, Matchar D, Divine GW, Feussner J. 1992. Measurement of motor recovery after stroke: outcome assessment and sample size requirements. Stroke; 23:1084-9.

Fitten LJ, Perryman KM, Wilkinson CJ, Little RJ, Burns MM, Pachana N, Mervis R, Malmgren R, Siembieda DW, Ganzell S. 1995. Alzheimer and vascular dimentias and driving. JAMA; 273:1360-1365.

Katz JN, Larson MG, Phillips CB, Fossel AH, Liang MH. 1992. Comparing measurement sensitivity of short and longer health status instruments. Med Care; 30:917-925.

Legh-Smith J, Wade DT, Langton Hewer R. 1986. Driving after stroke. J Roy Soc Med; 79:200203.

Nouri FM, Tinson DJ, Lincoln NB. 1987. Cognitive ability and driving after stroke. Int Disabil Stud; 9:110-115.

Schanke A, Sundet K. 2000. Comprehensive driving assessment: Neuropsychological testing and on-road evaluation of brain injured patients. Scan J Psych; 41:113-121.

Sivak M, Olson PL, Kewman DG, Won H, Henson DL. 1981. Driving and perceptual/cognitive skills: behavioral consequences of brain damage. Arch Phys Med Rehabil; 62:476-483.

Sundet K, Goffeng L, Hofft E. 1995. To drive or not to drive: neuropsychological assessment for driver's license among stroke patients. Scan J of Psych; 36:47-58. 